Old Dominion University

ODU Digital Commons

1984

Trace-Elements in IImenite - A Way to Discriminate Provenance or Age in Coastal Sands

Dennis A. Darby

Follow this and additional works at: https://digitalcommons.odu.edu/oeas_fac_pubs

Part of the Geochemistry Commons, and the Geology Commons 


\title{
Trace elements in ilmenite: A way to discriminate provenance or age in coastal sands
}

\author{
DENNIS A. DARBY Department of Geological Sciences, Old Dominion University, Norfolk, Virginia 23508
}

\section{ABSTRACT}

Trace elements and Ti percentage in ilmenite grains magnetically separated from modern and late Pleistocene coastal sands of southeastern Virginia and northwestern North Carolina were used to distinguish different deposits. Multivariate analysis of ilmenite composition ( $\mathrm{Ti}, \mathrm{Mn}, \mathrm{Mg}, \mathrm{Cr}, \mathrm{V}, \mathrm{Ni}$, and $\mathrm{Cu}$ ) from coastal deposits and potential source rivers enabled the identification of dominant source rivers. Using the traceelement content of one mineral instead of heavy-mineral suites eliminated most of the hydraulic sorting, selective weathering, and intrastratal solution problems that often obscure heavy-mineral provenance determinations. Most ilmenite grains lacked exsolution or twinning, which are common to ilmenite; however, there were no significant optical differences between river and coastal deposits, and thus weathering effects were considered to be negligible in provenance determinations based on ilmenite composition.

Owing to the dynamic mixing of beach sands during deposition, they contained more homogeneous ilmenite trace-element values than did river or bay sands. Late Pleistocene and modern beach deposits were compositionally similar, but different from associated bay sands. Bay sands were more similar to different source river deposits than were beach sands. Despite a similar primary or distal provenance, subtle differences in the mixture of proximal sources were revealed between the ilmenite composition of samples from a modern arid a late Pleistocene beach deposit. Besides aiding in provenance determination, ilmenite trace-element content thus might be used for dlistinguishing beach deposits of different ages and for subsurface correlation of discontinuous segments from a barrier-island chain or other similarly wellmixed sand deposit.

\section{INTRODUCTION}

Although heavy minerals provide one of the most useful keys to provenance, their application has proven more successful in delineating source drainage basins along fluvially dominated coasts, such as the United States Gulf Coast, than along estuary-dominated coasts, such as the United States Atlantic Coast (van Andel, 1960; Pilkey, 1963; Davies and Moore, 1970). Whereas the sands of beach and inner-shelf deposits from New Jersey to Florida ultimately were derived from both Appalachian and Piedmont sources, the heavy minerals in these sands are generally the same throughout these deposits (Giles and Pilkey, 1965; Milliman and others, 1972). Relative abundances of heavy minerals, primarily epidote, hornblende, and staurolite, have delineated a few provinces along the southeastern United States coast (Gorsline, 1962; Pilkey, 1963) and even more provinces north of Delaware (Ross, 1970). Except for a few studies along the northeastern United States shelf such as by Kelling and others (1975), wherein specific drainage basins have been linked with pre-Holocene shelf-edge deposits, determinations of heavy-mineral provenance for Atlantic coastal deposits, especially those south of Delaware, have been limited (Thom and others, 1972; Cazeau, 1974).

The lack of diagnostic heavy minerals for definitive provenance determinations is due to hydraulic sorting, according to some studies (Swift and others, 1971; Carver, 1971), and to weathering or intrastratal solution, according to others (Neiheisel, 1962; Hails and Hoyt, 1972). Pilkey (1963) even suggested that the lack of variation in heavy minerals on the southeastern United States shelf and slope is due to a similar provenance for most of the major rivers in this area.

In an attempt to avoid most of the hydraulio sorting and weathering problems inherent with provenance interpretations based on heavymineral suites, especially where sediments are frequently reworked, this paper presents the results of the use of the trace-element content of ilmenite for characterizing different depositional units of southeastern Virginia and North Carolina and for determining the provenance of these units. In other areas, investigators have used the limited trace-element content of quartz for the provenance of fluvial sands (Dennen, 1967; Suttner and Leininger, 1972) or the $\mathrm{Ti}$ and $\mathrm{Cr}$ contents of the magnetic fraction of beach sands, chiefly magnetite, for sediment dispersal patterns (Luepke, 1980). Promising results on the limited varieties of quartz trace elements (Herrera and Heurtebise, 1974) suggest that ilmenite, with its variety of intergrowths (Rao and Rao, 1965) and trace elements (Buddington and Lindsley, 1964), is an overlooked mineral for trace-element provenance studies.

\section{RATIONALE FOR USING ILMENITE}

Ilmenite is the most abundant opaque mineral and usually the most abundant heavy mineral in the southeastern United States coastal sands of either Holocene or Pleistocene age (Go sline, 1962; Neiheisel, 1962; Hails and Hoyt, 1972; Force and Geraci, 1975). Ilmenite, moreover, is relatively easy to separate using the Franz isodynamic magnetic separator (Rosenblum, 1958; Lumpkin and Zaikowski, 1980) and has a variety of trace elements depending on its paragenesis (Hutton, 1950; Gjelsvik, 1957; Deer and others, 1962; Buddington and Lindsley, 1964). The slightly greater durability of ilmenite compared to magnetite (Dryden and Dryden, 1946; Pettijohn, 1957), along with the possible righer ilmenite content in source rocks, might account for its far greater abundance in coastal plain deposits of the eastern United States.

Besides substitutions in the crystal lattice, differences in $\mathrm{V}, \mathrm{Mg}, \mathrm{Ni}, \mathrm{Mn}, \mathrm{Cr}, \mathrm{Cu}$, and even $\mathrm{Ti}$ might be due to intergrowths or exsolution of hematite, magnetite, rutile, and spinel (ulvospinel), or to partial alteration of ilmenite to

Geological Society of America Bulletin, v. 95, p. 1208-1218, 7 figs., 2 tables, October 1984. 
leucoxene (Rao and Rao, 1965; Ramdohr, 1969). The degree of alteration of ilmenite can be determined by reflected light microscopy (Bailey and others, 1956). This alteration affects the trace- and major-element composition, and so samples with significantly greater alteration than found in source rivers can be excluded. Besides recognition of alteration, the mineralogy of the exsolved phases can be determined under reflected light, and it can assist in evaluating the trace-element variations.

\section{STUDY AREA}

A 90-km segment of the Outer Banks beach north of Cape Hatteras was sampled at regular intervals (Fig. 1). This beach contains a relatively uniform heavy-mineral suite (Flores and Shideler, 1982), the proximal source of which has been interpreted as the inner shelf (Swift, 1975). A late Pleistocene barrier sand was also sampled at regular intervals along a $90-\mathrm{km}$ segment of the Hickory Scarp (Oaks and Coch, 1973) (Fig. 1). Sampling was done by hand auger, except where sand pits were available. These beach deposits were sampled from 1 to 3 $m$ below the crest of the Hickory Scarp, and they correspond to the Kempsville Formation of Oaks and Coch. At depths of 4 to $10 \mathrm{~m}$, samples were obtained from a shelly sand, the Norfolk Formation as redefined by Oaks and Coch, which yielded uranium series dates on solitary corals of $\sim 75,000$ yr B.P. (Oaks and others, 1974; Cronin and others, 1981). This facies, originally interpreted as nearshore marine by Oaks and Coch, was recently interpreted as bay to open bay (Jasper, 1982), with no depositional break between the Norfolk and Kempsville Formations in the Hickory Scarp area (Jasper and Darby, 1983).

In order to determine the dominant source rivers for these coastal deposits, several samples were collected along the banks of the potentially important rivers (Fig. 1). In most cases, samples were obtained from both the estuarine and fluvial portions of these rivers. Nearly all of the riverine samples were taken close to the fall line or downstream terminus of the fluvial segment of the rivers so as to represent the ilmenite suite from the entire drainage basin, because the heavy-mineral assemblage has been shown to change downstream due to tributary input and other factors (Stow, 1939). The estuarine segments might have a significant contribution from the adjacent coastal plain formations that outcrop in cliffs in many places along these estuaries in addition to upstream and estuary-mouth sources (Meade, 1969; Nichols, 1972). One sample (JR-1) was collected from the Rockfish River, which drains an ilmenite-bearing anorth- osite area before emptying into the James River, in Nelson County, Virginia (Minard and others, 1976).
Owing to the location of the coastal deposits from the Outer Banks and Hickory Scarp between the entrance of the Chesapeake Bay and

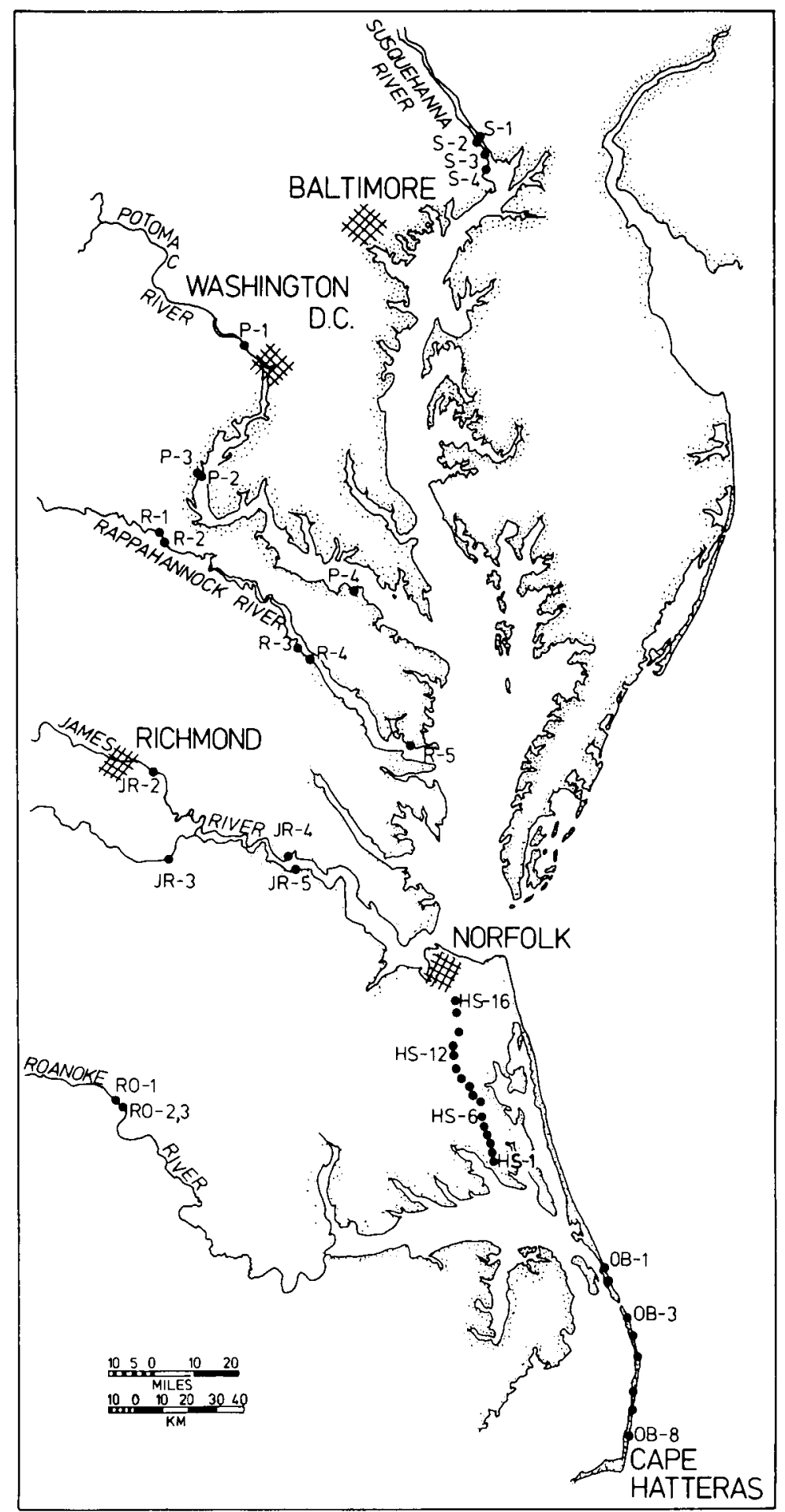

Figure 1. Location map of ilmenite sand samples. Sample JR-1 is from a tributary of the James River, the Rockfish River, Nelson County, Virginia, located in the Blue Ridge Province. Sample sites labeled HS are from the Hickory Scarp, and those labeled $\mathrm{OB}$ are from the Outer Banks. 
the Albemarle Sound, the important source rivers sampled were the Susquehanna, Potomac, Rappahannock. James, and Roanoke Rivers. Although other rivers could contribute ilmenite grains to these deposits, their input is thought to be significantly less than that of the rivers sampled. This supposition is based on the present knowledge of sediment dispersal from major rivers such as the Susquehanna and Hudson Rivers during glacioeustatic low sea level. At these times, sediments generally moved across the shelf through fluvial channels in a southeasterly direction to the heads of canyons on the continental slope (Hubert and Neal, 1967; Rona, 1970; Kelling and others, 1975). During the next transg:ession, some of these fluvial deposits were reworked and moved landward to form barrier is.ands and other coastal or nearshore deposits along with sediments directly from the land either from shoreline erosion or longshore drift with some input by local rivers (Giles and Pilkey, 1965; Swift, 1975; Swift and others, 1977).

\section{ANALYTICA.L TECHNIQUES}

Samples wele wet-seived through a $4 \phi$ sieve to remove silt and salts and then dry-sieved at $0.5 \phi$ intervals. The $2 \phi$ to $4 \phi$ size was used for ilmenite analysis because nearly all of the ilmenite was contained in this size interval.

Some of the samples were separated using tetrabromethane, but later replicates showed no difference in 1race-element content when this step was eliminated; therefore, most samples were magnetically separated without heavyliquid separation. The minor amounts of magnetite and titaniferous magnetite were removed by a hand magnet and the 0.1-amp setting on the Franz separator, using a forward and side slope of $15^{\circ}$ and $25^{\circ}$, respectively. The $0.1-$ to $0.3-$ amp Franz separation for ilmenite was used in all samples. This fraction was sonified in deionized water to remove adhering particles and coatings, dried, and examined under a binocular microscope where nonopaque, nonblack grains were removec. with a fine brush. A portion of this cleaned sample was ground to $<100$ mesh and analyzed by X-ray diffraction (XRD). If nonilmenite peaks were detected, the sample was passed through the Franz again at 0.1 and $0.3 \mathrm{amp}$ and recleaned under the microscope. Parts of several samples, including all river samples upstream of the estuaries and samples showing nonilmenite XRD peaks, were mounted on glass slides and polished for reflected light microscopy (technique from Sanders and Kravitz, 1964).

Although rost of the separated grains were ilmenite, a few magnetite and hematite grains, as well as ilmenite grains with hematite and, less commonly, magnetite intergrowths, were detected in many samples. A special effort was made to detect and remove chromite grains, because $\mathrm{Cr}$ is one of the elements measured. Only 3 samples, 2 from the Susquehanna River and 1 from the Potomac River, contained any chromite after the first cleaning, and these sarnples had less than 2 or 3 grains from $>400$ grains counted from each sample.

The cleaned ilmenite samples were ground, weighed, and mixed with five times as much $\mathrm{LiBO}_{3}$. The mixture was fused at $950^{\circ} \mathrm{C}$ for 15 min and immediately dissolved in $20 \%$ tripledistilled $\mathrm{HNO}_{3}$, which was later diluted to a known volume of $10 \% \mathrm{HNO}_{3}$. The seven elements studied were determined by atomic absorption analysis.

\section{Replicate and Sample Variance}

The same trace elements were found in all ilmenite samples; thus, for the trace-element content of ilmenite to be useful in province characterization or in provenance determination, there must be adequate trace-elemert differences among the potential source areas and among the coastal deposits. These differences must be significantly greater than those in replicate analyses. The differences within a single drainage basin as represented by samples near the terminus of the riverine portion as well as samples from the estuarine portion must be less than the differences among all source rivers in order to ascertain dominant source rivers.

The standard deviations among 56 samples from 5 potential source rivers and the coastal deposits of southeast Virginia and northeast North Carolina were 19 to 121 times greater than the average standard deviation or error of 24 replicate samples (Table 1 ). The river samples, averaged together, showed much greater standard deviation for each metal than did beach samples. Typically, the sample group with the lowest standard deviation for each inetal was either the Outer Banks or Hickory Scarp beach, except for two metals (Table 1). The highest within-group variations occurred in river samples for each metal except $\mathrm{Mg}$ and $\mathrm{V}$, which were highest in late Pleistocene bay deposits. River samples thus contained more compositional variation than did coastal samples.

The differences between rivers were greater than within each river basin for each metal except perhaps $\mathrm{Mn}, \mathrm{V}$, and Ni. Analysis of variance (ANOVA) demonstrated that the amonggroup metal variance was significantly greater than the within-group metal variance for most elements among the five rivers tested, clespite the small number of degrees of freedom. When all sample groups were included, $F$ values from ANOVA were significant ( $95 \%$ level) for all metals except $\mathrm{Mn}$, which was significant at only the $89 \%$ level.

\section{PROVENANCE BASED ON TRACE ELEMENTS}

Although rivers supply ilmenite grains from primary-source rocks, estuaries can be important proximal sources for beach and bay sands. For barrier-beach deposits, the sand is probably flushed out of the estuaries and onto the shelf during a sea-level regression before it is moved onto the beach by the next transgress.on. Given that estuaries can receive sand from both upstream and offshore sources, as well as from older coastal deposits outcropping along the estuary, the riverine and estuarine samples of all but the Roanoke River are compared separately to the sampled coastal bay and beach deposits in Figures 2 and 3 , in order to detect the possible influx into each estuary of ilmenite with a composition different from that of the riverine segment.

Although metal differences exist between

\begin{tabular}{|c|c|c|c|c|c|c|c|}
\hline & $\begin{array}{c}\mathrm{Ti} \\
\text { (\%) }\end{array}$ & Mn & $\mathbf{M g}$ & $\mathrm{v}$ & $\mathrm{Cr}$ & $\mathrm{Ni}$ & $\mathrm{Cu}$ \\
\hline $\begin{array}{c}\text { Replicates } \\
\mathbf{n}=\mathbf{2 4}\end{array}$ & 3.5 & 17 & 16 & 9 & 11 & 7 & 4 \\
\hline $\begin{array}{l}\text { All samples } \\
\qquad \mathrm{n}=56\end{array}$ & 4.5 & 2,063 & 940 & 617 & 738 & 152 & 71 \\
\hline $\begin{array}{l}\text { Lowest among all groups } \\
\text { (Group symbols) } \\
\text { n }\end{array}$ & $\begin{array}{l}1.4 \\
(0) \\
8\end{array}$ & $\begin{array}{r}450 \\
(0) \\
8\end{array}$ & $\begin{array}{r}246 \\
(\mathrm{H}) \\
15\end{array}$ & $\begin{array}{r}52 \\
\text { (S) } \\
4\end{array}$ & $\begin{array}{r}49 \\
(0) \\
8\end{array}$ & $\begin{array}{c}11 \\
(\mathrm{O}) \\
8\end{array}$ & $\begin{array}{r}11 \\
(J) \\
5\end{array}$ \\
\hline $\begin{array}{l}\text { Highest among all groups } \\
\text { (Group symbols) } \\
n\end{array}$ & $\begin{array}{l}5.6 \\
(\mathrm{~J}) \\
4\end{array}$ & $\begin{array}{r}4,664 \\
\mathbf{R o}) \\
3\end{array}$ & $\begin{array}{r}1,415 \\
(\mathbf{B}) \\
8\end{array}$ & $\begin{array}{r}1,191 \\
(\mathbf{B}) \\
8\end{array}$ & $\begin{array}{r}1,660 \\
(S) \\
4\end{array}$ & $\begin{array}{r}333 \\
(\mathbf{R o}) \\
3\end{array}$ & $\begin{array}{r}119 \\
(5) \\
4\end{array}$ \\
\hline
\end{tabular}


riverine and estuarine samples in each river, the large variations (standard deviations) on these mean metal values obscure recognition of significant changes. Of all the metal differences from riverine samples (Fig. 2) to estuarine samples (Fig. 3), only the slight $\mathrm{TiO}_{2}$ decrease in the Potomac and James Rivers, the $\mathrm{Mn}$ decrease in the Susquehanna River, the $\mathrm{Cr}$ decrease in the Potomac River and increase in the James River, the Ni decrease in the Susquehanna and Potomac Rivers, and the $\mathrm{Cu}$ decrease in the Susquehanna and Rappahannock Rivers were larger than one standard deviation for the average of each river (Table 2).

There is no significant trend for any metal in more than two rivers. On account of this, the high variance among ilmenite metal contents in river samples, and the low number of downstream changes exceeding one standard deviation, the metal values from riverine and estuarine samples were combined for each river for the remaining discussion (Table 2).

Although histograms of average metal values display possible relationships between certain rivers and the beach or bay deposits, multivariant statistical tests such as stepwise discriminant analysis are better suited to reveal and to test relationships among the sampled deposits (Davis, 1973; Flores and Shideler, 1982). The plots of the first 2 discriminant functions that account for $77 \%$ of the variance reveal several important relationships (Fig. 4):

1. The samples from the Susquehanna River form a diverse but unique cluster that differs significantly from modern and Pleistocene beach sands in southeastern Virginia or North Carolina. This river also differs from the other rivers, suggesting that this northern Appalachian source for ilmenite is different from the central Appalachian source drained by the James, Rappahannock, and Potomac river systems.

2. The modern and late Pleistocene beach sands form tight clusters close to one another, suggesting a very homogeneous mix of ilmenite grains from similar sources. Despite this close cluster on the discriminant plot, a Hotelling's $\mathrm{T}^{2}$ test (Morrison, 1967) indicated that these 2 beach deposits are significantly different at the 95\% level of confidence.

3. The samples from the modern and late Pleistocene beach deposits are associated most closely with the James River, Rappahannock River, and Potomac River, suggesting a probable central Appalachian provenance for these beach deposits. Of all the river samples from these three rivers, those nearest the mouths (samples labeled 5 in Fig. 4) are closest to the beach samples on the discriminant plot.

4. The late Pleistocene bay sands (older Hickory Scarp strata in Fig. 4) form at least two clusters that are separate from the conformable but overlying beach sands. These bay sands plot more closely to various river samples that might indicate a more direct source that has not undergone as much mixing as the beach sands. For example, one cluster of bay sands is associated with samples from the Roanoke River, and another cluster is more closely grouped with samples from the James River and the Potomac River.

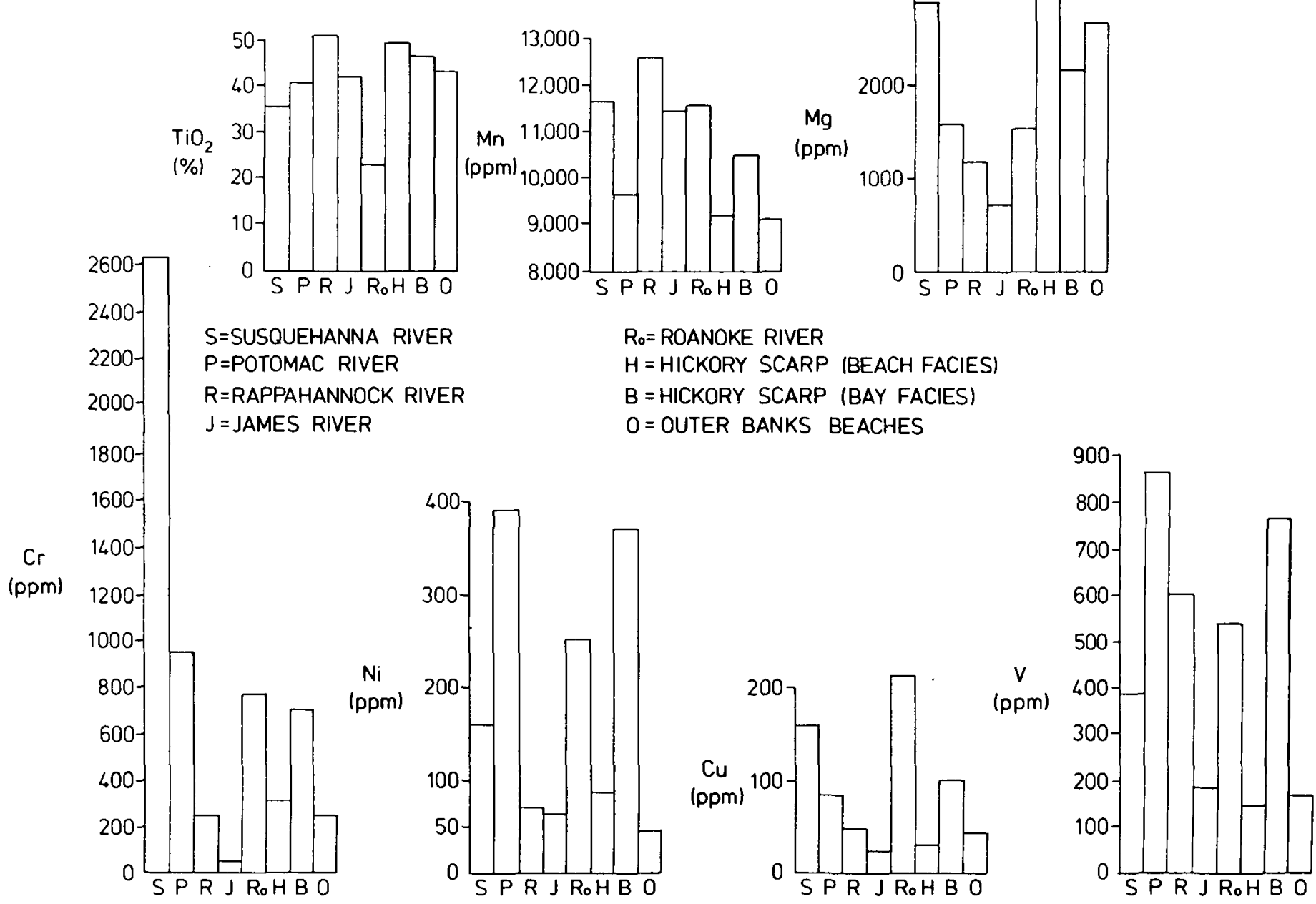

Figure 2. Average trace elements and $\mathrm{TiO}_{2}$ percentage of ilmenite samples from the riverine portion of rivers compared to samples from Modern and late Pleistocene (H and $B$ ) coastal deposits. 


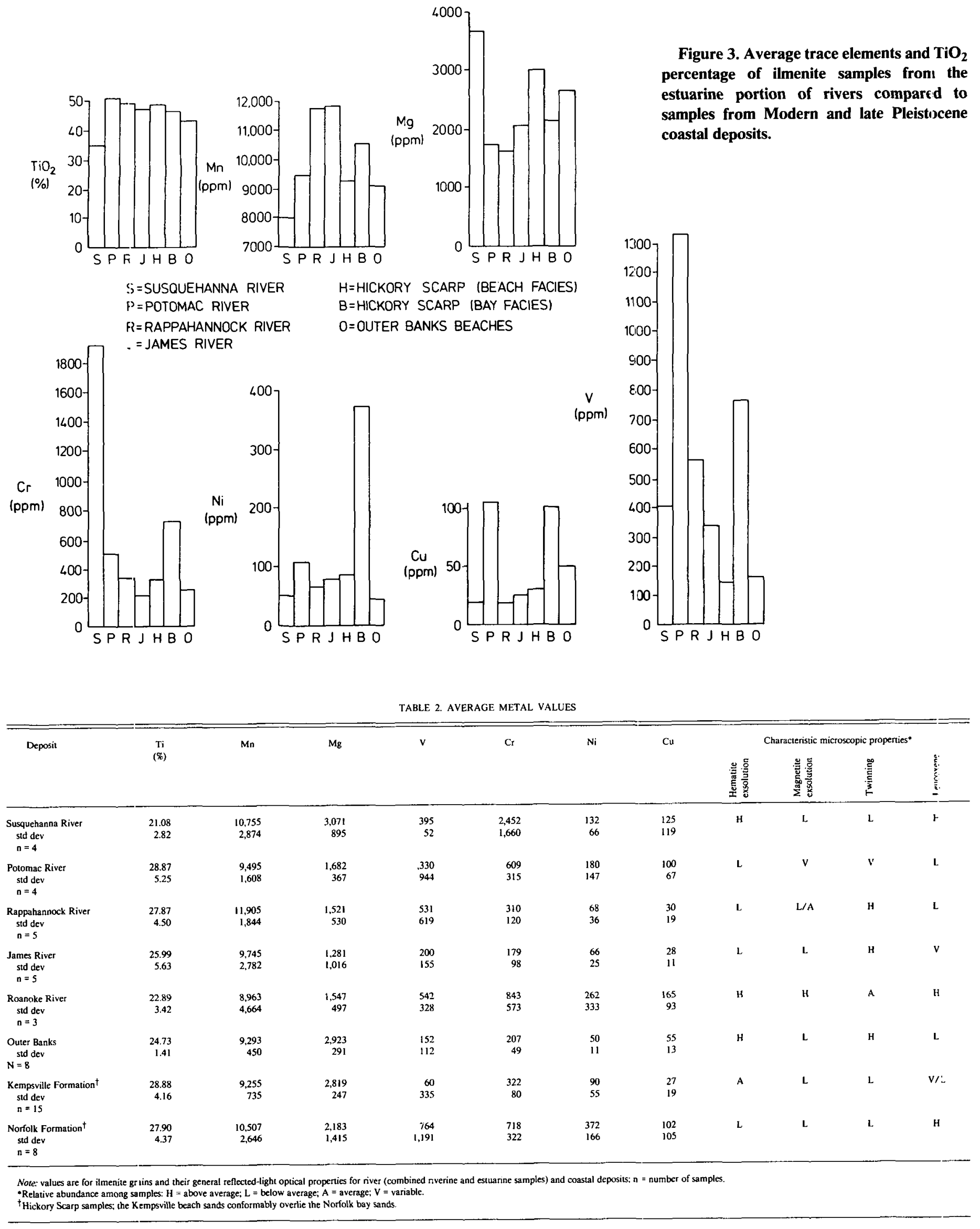



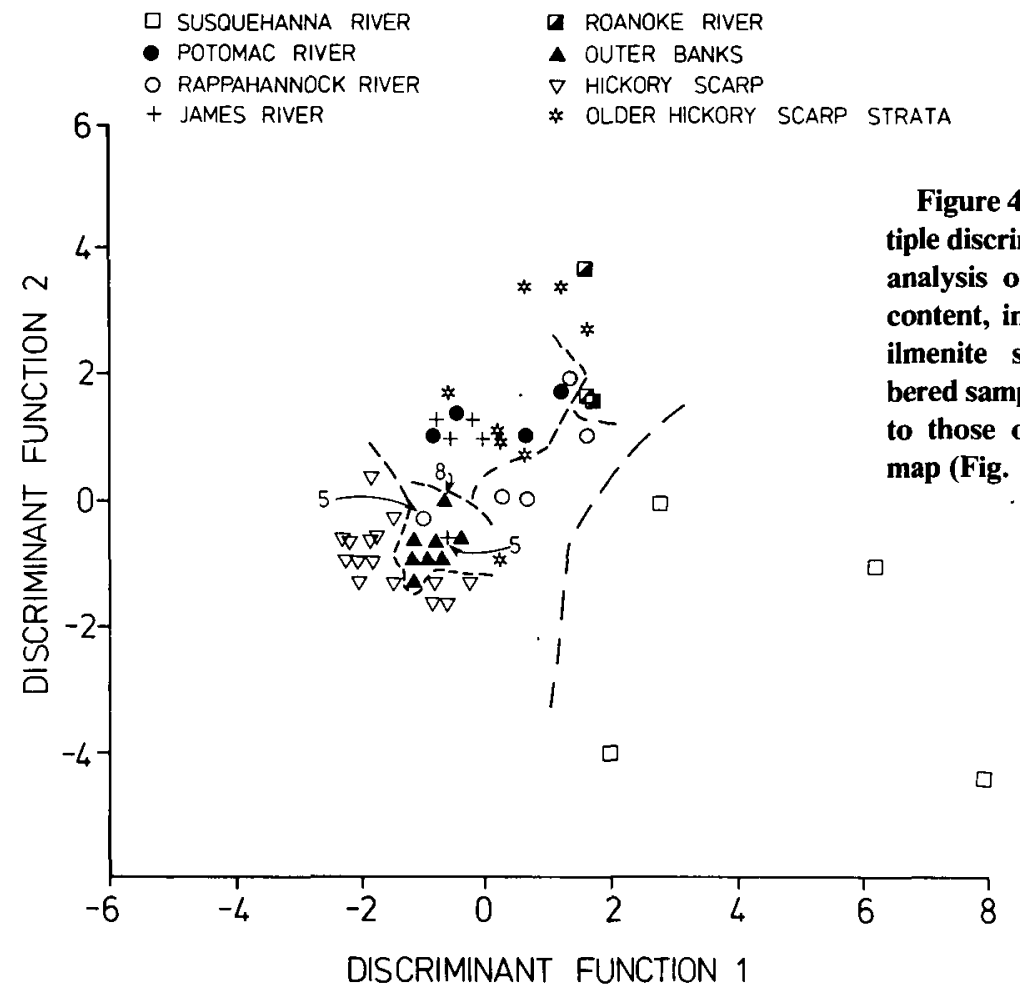

Although the first 3 discriminant functions were significant in defining the sampled groups, the third function accounted for only $13.7 \%$ of the variance and only slightly improved the separation of samples shown in Figure 4. This third discriminant function did, however, show a closer grouping of the Hickory Scarp bay sands to the Susquehanna River samples, especially samples S-3 and S-4, which are located closest to the Chesapeake Bay (Fig. 1).

The first discriminant function was defined primarily by $\mathrm{Cr}$ and $\mathrm{Mn}$ based on standardized canonical discriminant-function coefficients. The second function was defined chiefly by $\mathrm{Mg}$ and $\mathrm{Cu}$, and the third was defined by $\mathrm{Ni}$ and $\mathrm{Mg}$. Although $\mathrm{V}$ and $\mathrm{Ti}$ were not important until the fourth function, their removal was not indicated by within-group correlations that were below 0.5 for all elements. All 6 discriminant functions correctly classified $71 \%$ of the samples with an average probability of 0.76 that each sample belonged to its appropriate group. Factor analysis revealed similar relationships among sample groups as shown in Figure 4, but without known significance levels.

Using the classifying capability of the discriminant function, only the a priori group information for rivers was used to classify the coastal samples. All of the Hickory Scarp beach samples were classified with the James or Rappahannock Rivers, and the Outer Banks beach sands were classified with either the Potomac River or the Roanoke River, but at less than the 95\% confidence level. The low probability here is likely due to the lower number of bay samples in each cluster (Fig. 4).

\section{Effects of Coastal Mixing on Provenance}

Although the provenance or ultimate source of ilmenite in beach and bay sediments in the study area is primarily the Central Appalachian and Piedmont Provinces eroded by the James and Rappahannock Rivers and, to a lesser extent, the Potomac River, sediments delivered to

\section{PLEISTOCENE PROVENANCE AND DISPERSAL MODEL FOR S.E. VA.}

Figure 5. Generalized model of distal (primary) and proximal sources as well as sediment dispersal. Offshore and bay sources are reworked from distal sources in the Appalachian and Piedmont Provinces.

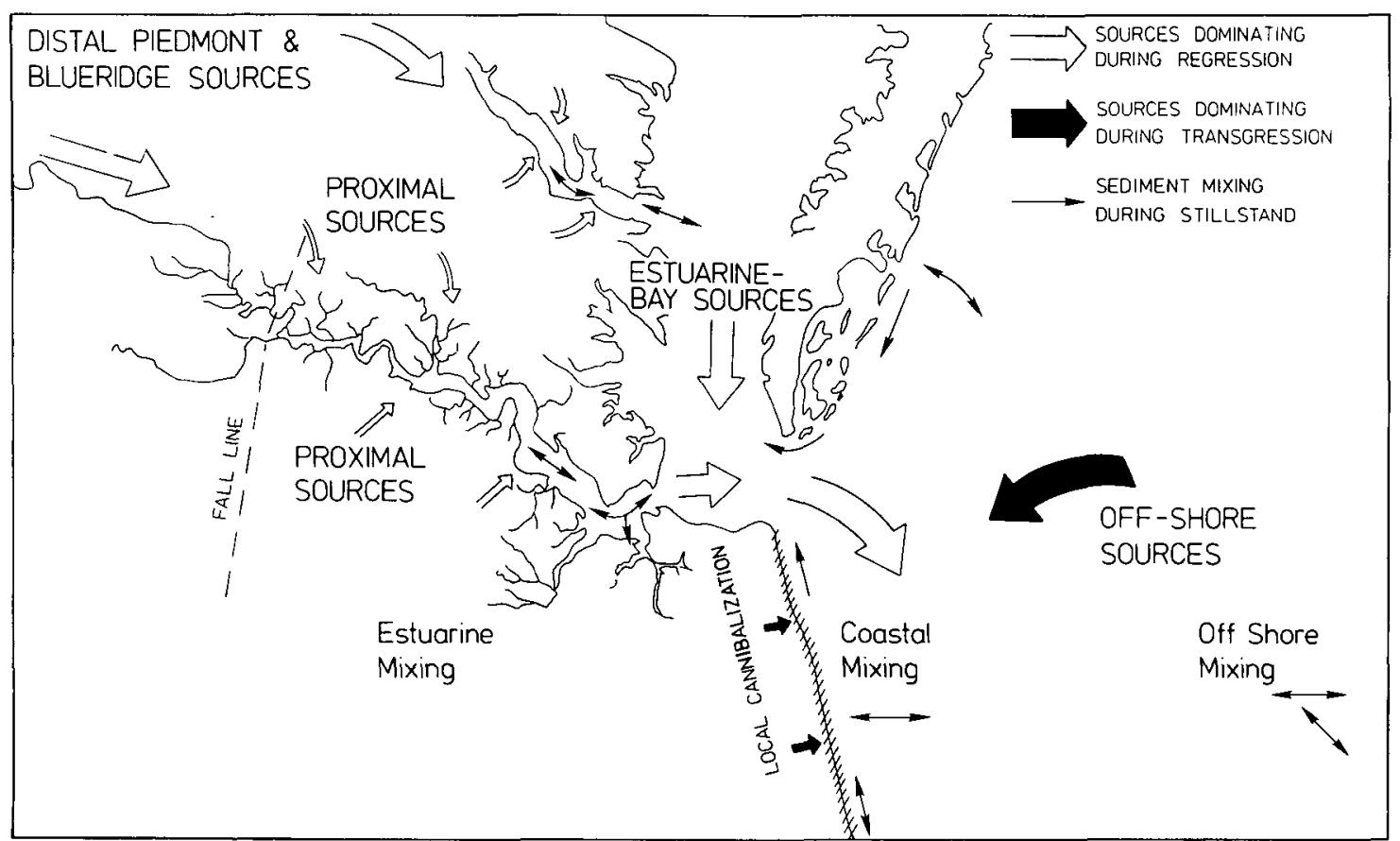


the coast undergo varying degrees of mixing depending on their environment of deposition. For example, beach sands probably have a variety of proximal sources as shown in Figure 5. The relative importance of these sources should vary with other factors, especially sea-level changes (Curray, 1964; Swift, 1975). In fact, subtle differences in the proportions from each proximal source might account for the small but statistically significant trace-element differences between modern and Pleistocene beach samples noted above. Regardless of the source of sands supplied to a beacl, the dynamics of the beach environment, esperially longshore drift, apparently result in a mix of ilmenite grains with a lower degree of trace-element variance and thus greater homogenei:y than bay or fluvial deposits (Table 2; Fig. 4).

The relative degree of mixing and reworking that occurs with the sand eventually deposited in a bay, beach, or other coastal environment affects the measurec. trace-element content from the ilmenite grains in this deposit. On the basis of the limited variety of deposits analyzed thus far, the bay sediments exhibit greater similarities with individual riviers or groups of rivers than do beach sediments (Fig. 4). This is probably because bay deposit: consist largely of sediment from nearby rivel systems, whereas adjacent beach sediments consist largely of sediment transported longshore and/or derived from off- shore. If so, a major provenance break occurs behind the beach. Of course, this depends on how close the bay sample is located to an inlet or bay mouth where beach sediments and bay sediments share more similar sources (Ludwick, 1970).

Ilmenite grains were nearly always smaller than $2 \phi(0.25 \mathrm{~mm})$, with the modal size between $3 \phi$ and $3.5 \phi$, approximately one phi size smaller than the modal quartz size. The ilmenite thus was at or near hydraulic equivalency with the quartz (Rittenhouse, 1943; Briggs, 1965; Young, 1966). Only 1 sample, JR-1, had abundant ilmenite coarser than $2 \phi$, and there was no difference in the trace-element content compared to the $2 \phi$ to $4 \phi$ ilmenite in this sample.

\section{Weathering Effects}

The ilmenite grains were relatively unweathered, as indicated by their optical properties in reflected light. Similar findings were noted for ilmenite grains in other coastal sands (Rao and Rao, 1965; Boctor, 1966).

Comparison of 28 polished ilmenite grain mounts from riverine, estuarine, bay, and beach environments indicated that all samples were weathered similarly, even river samples. According to microscopic criteria established by Bailey and others (1956) for the alteration of ilmenite, the $20 \%$ to $50 \%$ of the grains that showed signs of alteration fell into their early first stage of alteration. Most ilmenite grains did not contain twinning, intergrowths, or inclusions (Figs. $6 \mathrm{~A}-6 \mathrm{D}$ ); however, $25 \%$ of the ilmenite grains showed nonreflective lamellae or randorn pits (Figs. 6E and 6F). Some of these were spinel with hematite exsolutions both parallel to (0001) planes (Fig. 6E), but others were alterations of ilmenite to sphene or anatase, and possibly alteration of hematite lamellae to gcethite (Ramdohr, 1969; Boctor, 1966; Rao and Rao, 1965). Such lamellae occurred equally ir river and coastal samples (Figs. 6G and 6H). Leucoxene alteration of ilmenite was found in nearly all samples, but rarely in excess of $5 \%$ of the grains. Sonification might have removed some leucoxene rims, but because all samples were treated the same, this should not have affected traceelement comparisons.

In general, this rather unweathered condition for ilmenite is also seen in the low $\mathrm{TiO}_{2}$ content (Figs. 2, 3). Force and Geraci (1975) found slightly higher $\mathrm{TiO}_{2}$ values (between $51 \%$ and $55 \%$ ) for older, more weathered coasta -plain deposits in southeastern Virginia. Further evidence for the slight weathering in late Pleistocene and younger sediments can be found in the nonopaque heavy minerals that are imrnature with abundant hornblende and epidote in this
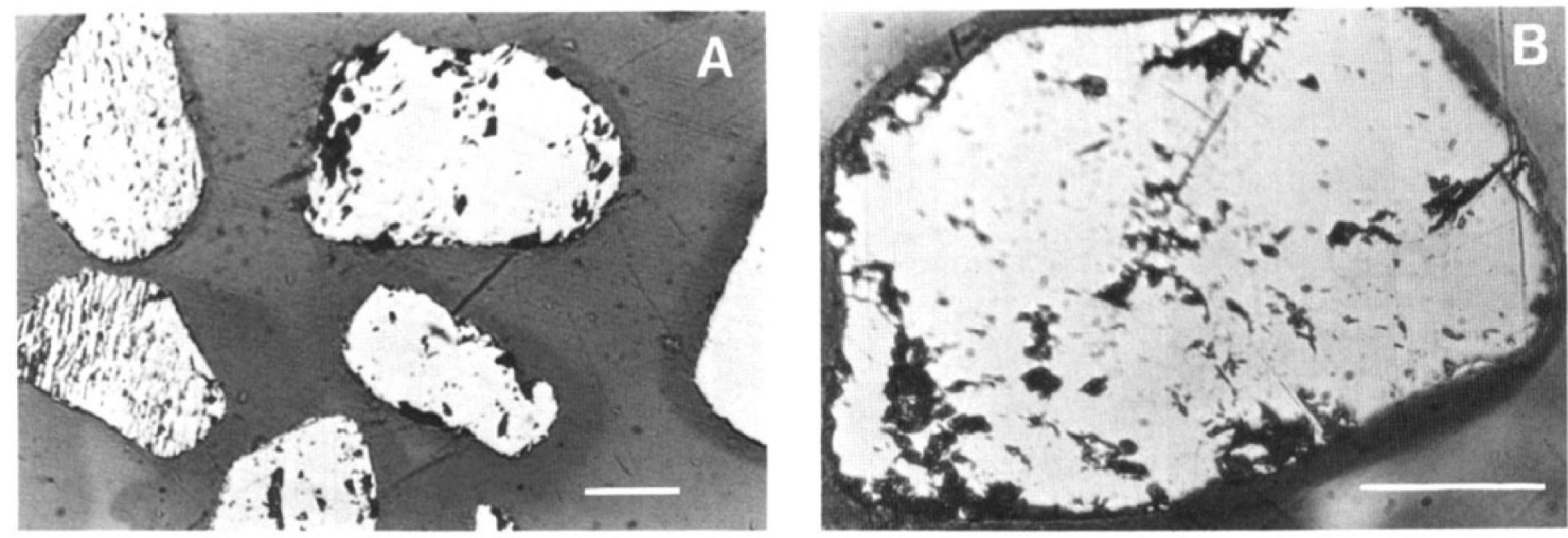

Figure 6. Photomicrographs of typical ilmenite grains (bar scale is $0.05 \mathrm{~mm}$ ). A. Mildly altered ilmenite from Hickory Scarp beach facies (HS-12) showing random pits and lamellae of nonreflective material with an absence of leuccixene rims. B. Similar weathering in modern beach grain (OB-4). C. Very early-stage alteration (or lack thereof) in an estuarine sample (JR-5) compared with similarly unaltered ilmenite (D) in Hickory Scarp Pleistocene beach (HS-12). E. Ilmenite with hematite exsolution lamellae (white) that are parallel to the nonreflective lamellae of spinel found in many samples (RO-1). F. Large ilmenite grain from JR-1, which is located closest to its source rock of all samples, showing minor leucoxene rims and nonreflective material. G. Ilmenite from JR-1 in X-nicols showing typical twinning and minor pitting. This twinning was somewhat less abundant farther downstream. H. Twinned ilmenite in $\mathrm{X}$-nicols showing two directions of parallel nonreflective lamellae (R-5). Although rare, this combination demonstrates the early development of this type of alteration before twinned grains are destroyeil. 
and other areas of the east coast (Giles and Pilkey, 1965). The higher degree of weathering or intrastratal solution noted for some late Pleistocene east coast deposits (Oaks and Coch, 1973; Neiheisel, 1962) might be more variable than previously reported. Significant differences in the degree and depth of shell leaching were noted in several sand pits along the Hickory Scarp. The trace-element content of ilmenite grains collected along a bedding plane on both sides of a leaching boundary in one pit showed no significant changes, however. The metal variations among leached and unleached samples were similar to variations among replicate sample splits.
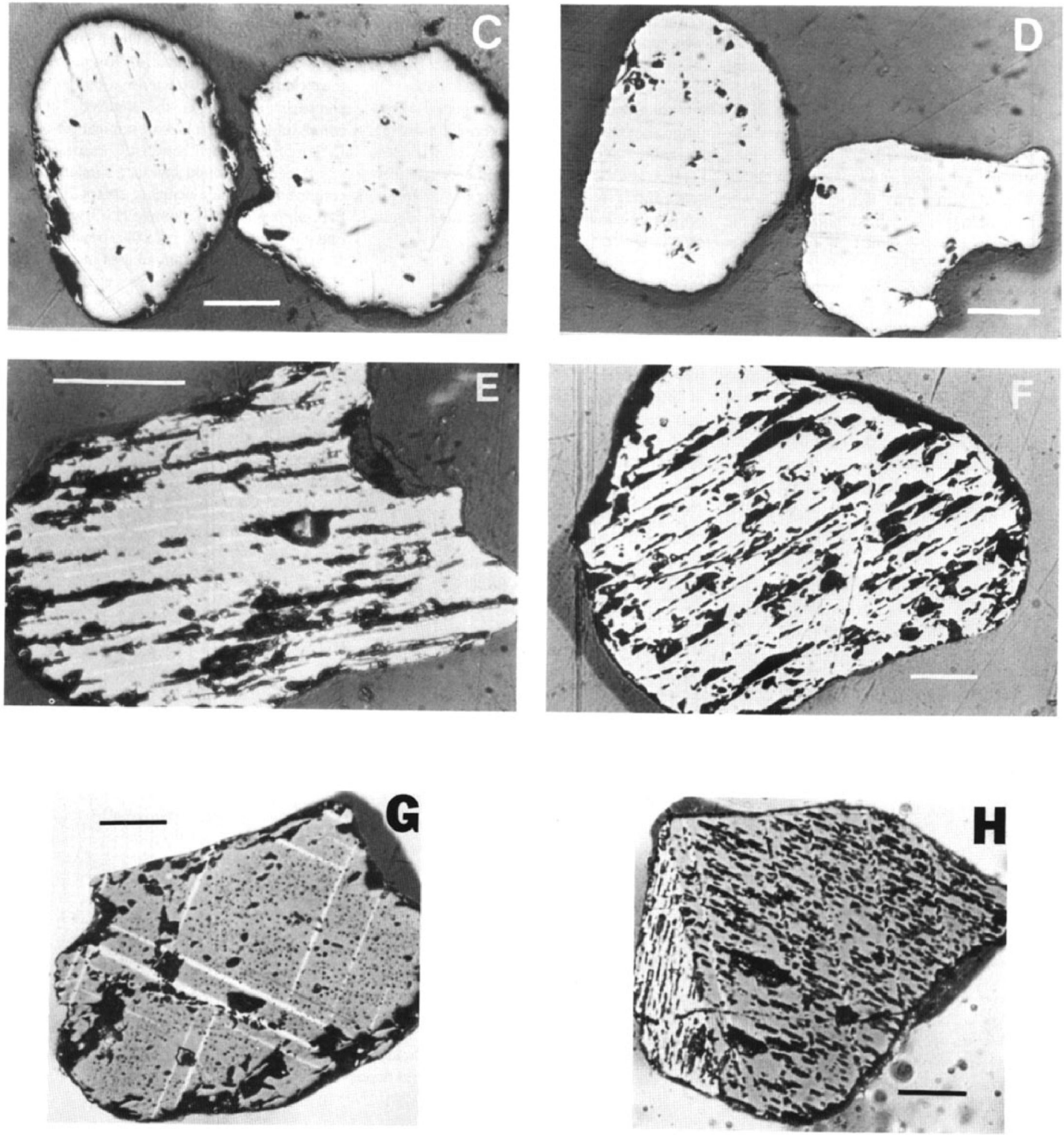

Figure 6 (Continued). 


\section{Exsolution Effects on Trace Elements}

The trace-eleme:at differences among sample groups cannot always be clearly explained by optical properties of ilmenite grains in reflected light. For example, the groups with the highest trace-element variation (Norfolk Formation, Susquehanna and Roanoke Rivers) all have above-average leucoxene abundance but different abundances of hematite or magnetite lamellae within ilmenite grains (Table 2). This might be due to the low number of samples from each group examined urider reflected light or to submicroscopic exsolution and lattice substitutions that affect the noted metal differences.

The sample grou.ps with more similar optical properties also were similar in most metals (Table 2) and plotied close together on the discriminant plot (Fig. 4). These were the James and Rappahannock: Rivers and the Outer Banks and Kempsville Formation beach sands (Figs. $6 \mathrm{~A}$ and $6 \mathrm{~B}$ ). These beach deposits differed from each other only in the abundance of ilmenite twinning. As the beach deposits previously were shown to be associated with the James and Rappahannock Rivers on the basis of discriminant classification of samples using ilmenite content, these four sample groups should have similar optical prcperties. Of those properties listed in Table 2, hematite exsolution is most different between these two rivers and these two beach deposits. This suggests that hematite exsclution is not a controlling factor for traceelement content, but further analysis is needed for confirmation.

The sample group with optical properties most consistent with a higher degree of weathering in the oldest sediment group, the Norfolk bay sands. These sands contain ilmenite with low abundances of hematite and magnetite exsclution, below-average occurrence of twinning, and above-average abundance of leucoxene (Table 2). The age difference between these sands and those of the overlying but conforma.ble Kempsville Formation should not be significant, however.

\section{IMPLICATIONS FOR STRATIGRAPHY}

Discriminant analysis of ilmenite trace-elt:ment data is useful in distinguishing sand bodies of different age and for identifying sampled units that are stratigraphically out of place or incorrectly correlated with a given sand body. In acldition, this technique might be expanded for distinguishing different depositional environments.
Often coastal-plain sand deposits lack diagnostic fossils and form discontinuous elongated lenses that are difficult to correlate in the subsurface. Although the shallow sand body of the Hickory Scarp is easily traced because of its geomorphic expression, this is not the cast: with more deeply buried sands. In that the ilmenite trace elements of the modern Outer Banks beach do not vary over distances of $90 \mathrm{~km}$ (Fig. 7) trace elements can characterize a barrier-island compartment such as the sampled Hatteras compartment (Fig. 1). An examination of the Hickory Scarp beach between Chesapeake Bay and Albemarle Sound reveals a similar unique composition of trace elements, except for one or two samples (Fig. 7). Sample HS-7 was nearly one phi size finer than any other beach sample. It was also collected from an area in which the Hickory Scarp is somewhat dissected. More detailed field work revealed that this sample was from a silty sand of possible lagoonal origi.?. For this reason, it was excluded from the average values in Figures 2 and 3 and from the discriminant analysis plot (Fig. 4). Discriminant analysis, with HS-7 included, classified this sample as belonging to the Hickory Scarp bay facies. The only other Hickory Scarp beach sample to have different metal values was HS-2, which differed for $\mathrm{Ni}$ and $\mathrm{Cu}$ only (Fig. 7). The mean size of

\section{OUTER BANKS BEACHES}
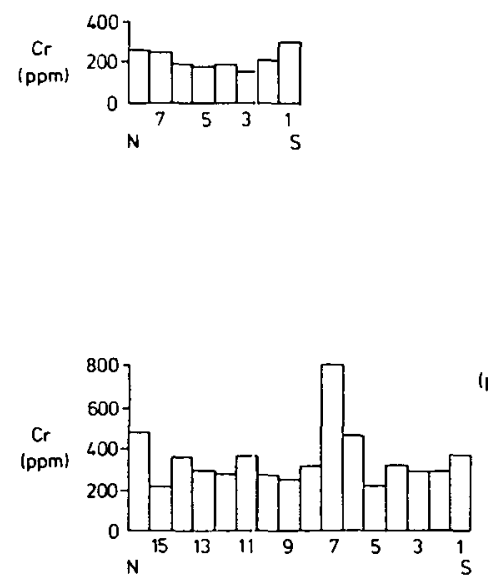
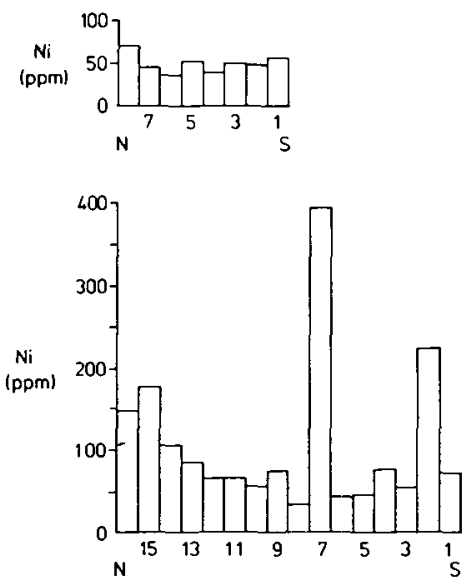
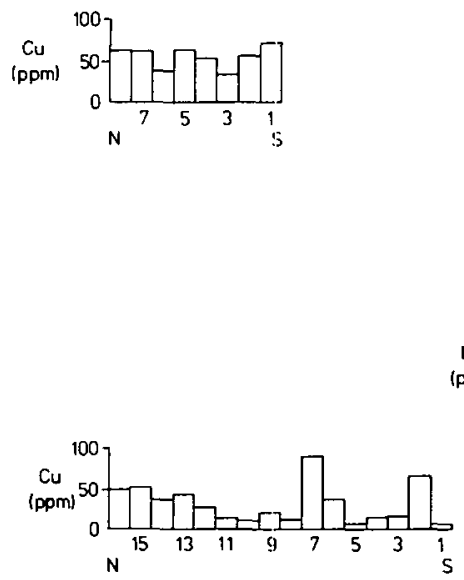
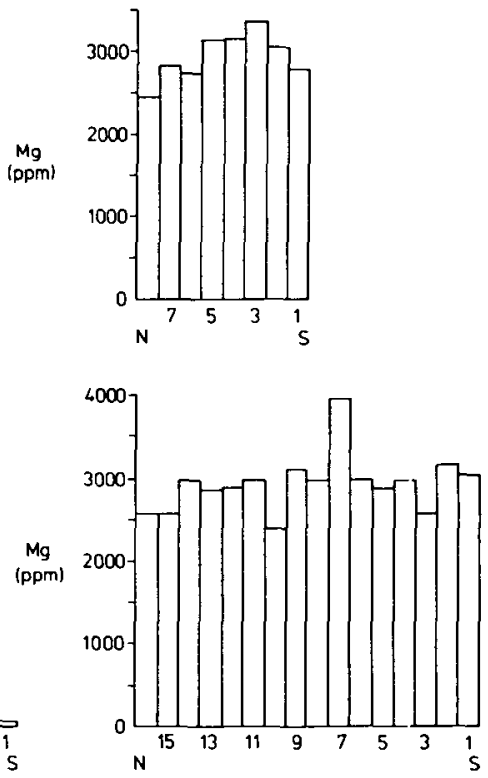

HICKORY SCARP BEACH FACIES (PLEISTOCENE)

Figure 7. Ilmenite trace-element analysis from Outer Banks beaches (modern) and Hickory Scarp barrier-island beaches (Pleistocene). There were no apparent differences in Ti percentage, $\mathrm{Mg}(\mathrm{ppm})$, and $\mathrm{Mn}$ (ppm) for either sand deposit. 
this sample was more than one phi size coarser than the average for this sand body, and the percentage of ilmenite recovered was much less, although of the same size as other Hickory Scarp beach sands. Despite these differences, discriminant analysis correctly classified this sample as belonging to the Hickory Scarp beach facies. Samples belonging to a particular sand body thus might be uniquely characterized and correlated with discriminant analysis of trace-element data.

As noted previously, there are significant differences in both the metal values and the average variance of metal values among depositional environments such as beach, bay, and fluvial deposits (Fig. 4; Tables 1 and 2). If this is due primarily to the relative dynamics of each depositional environment and secondarily to its proximity to ilmenite sources with unique traceelement contents, as suspected, then the inherent dynamic mixing processes of the environment as reflected by the trace-element suite might be used to help to distinguish certain facies or depositional environments. For example, beach deposits undergo the most dynamic mixing processes of all of the sampled environments. Not only is sediment well mixed along a barrierbeach segment, but the source of this sand is often the near-shore and adjacent shelf, which is made up of an earlier mix of different sources ultimately leading back to one or more rivers. For such well-mixed deposits as beaches, discriminant analysis of trace elements in ilmenite might supplement geophysical well logging and paleontologic data where sands cannot be physically traced or where more conventional correlation techniques are not definitive.

\section{CONCLUSIONS}

Trace elements in ilmenite effectively characterize and distinguish coastal deposits. Of the deposits studied, beach deposits contain the most homogeneous mix of ilmenite grains as defined by very little trace-element variance. The trace-element variance is far less than heavymineral variance along similar beach segments (Giles and Pilkey, 1965; Flores and Shideler, 1982). This is due to the greater influence of hydraulic sorting on heavy-mineral suites. Such effects, together with possible differences in ilmenite sources along the studied beach segments, are negligible for ilmenite composition (Fig. 7).
Weathering or intrastratal solution also have little if any effect on ilmenite trace-element content, on the basis of (1) the low trace-element variance either along the Hickory Scarp beach or across leached boundaries in this sand, (2) the similar optical properties of ilmenite from Pleistocene and modern beaches, and (3) the low $\mathrm{TiO}_{2}$ contents of the ilmenite.

Trace elements can be used to distinguish beaches with very similar provenances. The differences noted between the Hickory Scarp and Outer Banks ilmenite trace elements in Figure 4 and by Hotelling's $\mathrm{T}^{2}$ are primarily due to subtle differences in the proportions of different sources available to both beaches during their formation.

The metal differences between beach and bay environments were also significant and approximately of the same magnitude as differences between beach and river deposits (Fig. 2). In the study area, then, beach deposits can be distinguished from bay and estuarine deposits by ilmenite composition. Whether ilmenite trace elements can be used to distinguish bay deposits of different age or location from other bay or estuarine sands is uncertain.

No stratigraphic or locality grouping could be clearly discerned from the two clusters of Pleistocene bay samples on the discriminant plot (Fig. 4). A study of the modern distribution of ilmenite trace elements in the Chesapeake Bay is needed, along with a more extensive analysis of the Norfolk Formation bay facies, before the noted clustering among bay samples can be interpreted.

The method of using trace-element data in a single mineral obviously is not restricted to ilmenite or magnetite and quartz studied by others (Dennen, 1967; Luepke, 1980). Other minerals that might yield useful results would be zircon, tourmaline, garnet, and micas. For best results, the chosen mineral should be abundant in the deposits of interest, relatively easy to separate, resistant to weathering and diagenic alteration, and sufficiently complex in its paragenesis to yield significant differences in traceelement content from its primary-source rocks.

Certain minerals can be used to suggest a metamorphic or igneous source of varying specificity, depending on the minerals present. Unlike heavy-mineral provenance, ilmenite trace-element provenance determination at present requires direct knowledge of the sourcearea ilmenite grains. Ilmenite occurs in a variety of rock types, and much more work needs to be done on its paragenesis and corresponding traceelement content (Buddington and Lindsley, 1964), as well as on the effects of alteration on trace elements (Bailey and others, 1956), before provenance studies using ilmenite composition can be determined without analysis of source ilmenite grains. Once the ilmenite grains from source rivers are analyzed, composition of detrital ilmenite becomes a powerful tool that avoids most of the sorting and weathering problems inherent with heavy-mineral provenance.

\section{ACKNOWLEDGMENTS}

This paper was improved by the constructive criticism and encouragement of Eric Force of the U.S. Geological Survey in Reston, Virginia, and John Ludwick of Old Dominion University. I thank Joseph Rule and Ram Dahiya of Old Dominion University for advice on chemical analysis and statistical analysis, respectively. Y. Wen, A. Evans, W. Frasier, and A. Robbins assisted at various stages of sample collection and processing; their help is warmly appreciated.

\section{REFERENCES CITED}

Bailey, S. W., Cameron, E. N., Spedden, H. R., and Weege, R. J., 1956, The alteration of ilmenite in beach sands: Economic Geology, v. 51 p. 263-280.

Boctor, N. Z., 1966, Ore-microscopic studies of the opaque minerals in RosettaDamietta black sands [M.S. thesis]: Cairo, Egypt, Cairo University, 78 p.

Briggs, L. I., 1965, Heavy mineral correlations and provenances: Journal of Sedimentary Petrology, v. 35, p. 939-955.

Buddington, A. F., and Lindsley, D. H., 1964, Iron-titanium oxide minerals and synthetic equivalents: Journal of Petrology, v. 5, p. 310-357.

Carver, R. E., 1971, Holocene and late Pleistocene sediment sources, continental shelf off Brunswick, Georgia: Journal of Sedimentary Petrology, v. 41, p. $517-525$

Cazeau, C. J., 1974, Heavy minerals of Quaternary sands in South Carolina, in Oaks, R. Q., and DuBar, J. R., eds., Post-Miocene stratigraphy, central and southern Atlantic Coastal Plain: Logan, Utah, Utah State University Press, p. 174-178.

Cronin, T. M., Szabe, B. J., Ager, T. A., Hazel, J. E., and Owens, J. P., 1981, Quaternary climates and sea-levels of the U. S. Atlantic Coastal Plain Science, v. 211, p. 233-240.

Curray, J. R., 1964, Transgressions and regressions, in Miller, R. L., ed., Papers in marine geology: New York, MacMillan Company, p. 175-203.

Davies, D. K., and Moore, W. R., 1970, Dispersal of Mississippi sediment in the Gulf of Mexico: Journal of Sedimentary Petrology, v. 40 p. 339-353.

Davis, J. C., 1973, Statistics and data analysis in geclogy: New York, John Wiley \& Sons, $550 \mathrm{p}$

Deer, W. A., Howie, R. A., and Zussman, J., 1962, Rock-forming mineralsVolume 5, Non-silicates: New York, John Wiley \& Sons, 371 p.

Dennen, W. H., 1967. Trace elements in quartz as indicators of provenance Geological Society of America Bulletin, v. 78, p. 125-130

Dryden, L., and Dryden, C.. 1946, Comparative rates of weathering of some common heavy minerals: Journal of Sedimentary Petrology, v. 16, p. $91-96$.

Flores, R. M., and Shideler, G. L., 1982, Discriminant analyses of heavy minerals in beach and dune sediments of the Outer Banks barrier, North Carolina: Geological Society of America Butletin, v. 93, p. 409-413.

Force, E. R., and Geraci, P. J., 1975, Heavy minerals in Pleistocene(?) shoreline sand bodies of southeastern Virginia: U.S. Geological Survey Miscellaneous Field Studies Map MF-718.

Giles, R. T., and Pilkey, O. H., 1965, Atlantic beach and dune sediments of the southern United States: Journal of Sedimentary Petrology, v. 35, p. $900-910$.

Gjelsvik, T., 1957, Geochemical and mineralogical investigations of titaniferous iron ores, west coast of Norway: Economic Geology, v. 52, p. 482-498. Gorsline, D. S., 1962, Bottom sediments of the Atlantic shelf and slope off the southern United States: Journal of Geology, v. 71, p. 422-440. 
Hails, J. R., and Hoyt, J. H., 1972, The nature and occurrence of heavy minerals in Pleistocene and Holocene sediments of the lower Georgia coastal plain: Journal of Sedimentary Petrology, v. 42, p. 646-666.

Herrera, R., and Heurtebise. M.. 1974, Neutron activation analysis of trace elements in quartz sards: Its possibilities in the assessment of provenance: Chemical Geolosy, v. 14, p. 81-93.

Hubert, J. F., and Neal, W. J., 1967, Mineral composition and dispersal patterns of deep-sea sands in the western North Allantic perrologic province: Geological Socin:ty of America Bulletin, v. 78, p. 749-772.

Hutton, C. O., 1950, Studies if heavy detrital minerals: Geological Society of America Bulletin, v. 61, p. 635-716.

Jasper, A. K., 1982, Stratigraphy and depositional environments of a late Pleistocene barrier island complex, southeastern Virginia [M.S. thesis]: Norfolk, Virginia, Old Dominion University, $103 \mathrm{p}$

Jasper, A. K., and Darby. D. A., 1983, A reinterpretation of the stratigraphy and sedimentology for the late Pleistocene coastal deposits of southeastern Virginia: Geological Society of America Southeastern Section, Abstracts with Programs, v. 15, no. 2, p. 100.

Kelling, G., Sheng, H., and Stanley, D. J., 1975, Mineralogic composition of sand-sized sediment or the outher margin off the Mid-Atlantic states: Assessment of the influence of the ancestral Hudson and other fluvial Assessment of the influence of the ancestral Hudson and other ntwis

Ludwick, J. C.. 1970, Sand wives and tidal channels in the entrance to Chesapeake Bay: Virginia Journal of Science, v. 21, p. 178-184.

Luepke, G. 1980, Opaque minerals as aids in distinguishing between source and sorting effects on teach-sand mineralogy in southwestern Oregon:
and Journal of Sedimentars Perrology, 50 , p. 489-496.

Lumpkin, G. R., and Zaikowsl:i, A., 1980, A method for performing magnetic mineral separations in it liquid medium: American Mineralogist, v. 65 , p. $390-392$.

Meade, R. H., 1969, Landward transport of bottom sediments in estuaries of the Atlantic Coastal Plain: Journal of Sedimentary Petrology, v. 39, p. 222-234

Milliman, J. D., Pilkey, O. H., and Ross, D. A., 1972, Sediments of the continental margin off the eastern United States: Geological Society of America Bulletin, v. 83, p. 1315-1334.

Minard. J. P., Force, E. R., and Hayes, G. W., 1976, Alluvial ilmenite placer deposits, central Virginia: U.S. Geological Survey Professional Poper 959-H. 15 p.

Morrison, D. F., 1967, Multivariant statistical methods: New York, McGrilwHill, Inc., $339 \mathrm{p}$.

Neiheisel, J., 1962, Heavy-mineral investigation of Recent and Pleistocene sands of the lower coastal plain of Georgia: Geological Society of Arterica Bulletin, v 73 , p. 365-374.

Nichols, M., 1972, Sediments in the James River estuary, in Nelson, B. W., 'ad, Environmental framework of coastal plain estuaries: Geological Society of America Memoir 133, p. 169-212.

Oaks, R. Q., Jr., and Coch, N. K., 1973, Post-Miocene stratigraphy sind morphology, southeastern Virginia: Virginia Division of Mineral Resources Bulletin $82.135 \mathrm{p}$.

Oaks, R. Q., Jr., Coch, N. K., Sanders, J. E., and Flint, R. F, 1974, PostMiocene shorelines and sea levels, southeastern Virginia in Oaks, R. Q. Jr. and Dubar, $R$ eds, Post-Miocene stratigraphy, centrat $Q$ southern Atlantic Coastal Plain: Logan, Utah, Utah State University Press, p. 53-87.

Petijohn, F. J., 1957, Sedimentary rocks (2nd edition): New York, Harper and Row, 718 p.

Pilkey, O. H.. 1963. Heavy minerals of the U.S. south Atlantic continenta) stelf and slope: Geological Society of America Bulletin, v. 74, p. 641-648. Ramdohr, P., 1969. The ore minerals and their intergrowths: London, Pergamon Press, 1,174 p.

gamon Press, 1,174 p.
Rao, N. K., and Rao, G.V.U., 1965, Intergrowths in ilmenite of the beach sards of Kerala: Mineralogical Magazine, v. 35, p. $118-130$.

Riurenhouse, G. 1943, The transportation and deposition of heavy minerals: Geological Society of America Bulletin, v. 54, p. 1725-1780.

Rona. P. A.. 1970, Submarine canyon origin on upper continental slope of Cape Hatteras: Journal of Geology, v. 78, p. 141-152.

Rosenblum, S., 1958, Magnetic susceptibilities of minerals in the Franz isocy namic magnetic separator: American Mineralogist, v. 43, p. 170-173.

Ross, D. A.. 1970, Atlantic continental shelf and stope of the United StatesHeavy minerals of the continental margin from southern Nova Scotia to northern New Jersey; U.S. Geological Survey Professional Pare $529-\mathrm{G}, 40 \mathrm{p}$.

Sanders, J. E., and Kravizz, J. H., 1964, Mounting and polishing mineral grains on a microscopic slide for study with reflected and pola ized light: Economic Geology, v. 59, p. 291-298.

Stow, M. H., 1939, Reflection of provenance in heavy minerals of James River, Virginia: Journal of Sedimentary Petrology, v. 9, p. 86-91.

Suttner, L. H., and Leininger, R. K., 1972, Comparison of the traice elemen content of plutonic, volcanic, and metamorphic quartz from iouthwesten Montana: Geological Society of America Bulletin, v, 83, p. 1855-1862.

Swift, D.J.P., 1975, Barrier-island genesis: Evidence from the central Atlantic shelf, eastern U.S.A.: Sedimentary Geology, v. 14, p. 1-43.

Swift, D.J.P., Dill, C. E., Jr, and McHore, J., 1971, Hydraulic fracuonation of heavy mineral suites on an unconsolidated retreating coast: Journal of Sedimentary Petrology, v. 41, p. 683-690.

Swift, D.J.P., Nelson, T., McHore, J., Holliday, B., Palmer, H., and $\$$ hidier, G, 1977, Holocene evolution of the inner shelf of southern Virginia: Journal of Sedimentary Petrology, v. 47, p. 1454-1474.

Thom, B. G. Adams, R. D. Cazeau, C. J and Heron, S. D. Jr., 1972 Aspects of the texture and mineralogy of surficial sediments, Horry and Marion Counties, South Carolina: Journal of Southeastern Geolozy, v. 14, p. 39-58.

van Andel, Ti. H., 1960 , Sources and dispersion of Holocene sedime רis, nonthern Gulf of Mexico, in Shepard, F. P., Phleger, F. B., and tan Andel, Tj. H., eds., Symposium on Nonhwesi Gulf of Mexico: Tulsa, Tj. H., eds., Symposium on Northwest Gulf of Mexico: Tulsa,
Oklahoma, American Association of Petroleum Geologists, F. 34-55.

Young, E. J., 1966. A critique of methods for comparing heavy mintral suites Journat of Sedimentary Petrology, v. 36, p. 57-65.

Manuscript ReCeived ay THE Society June 8, 1983 ReVISED MaNUSCRIPT ReCEIVED FEBRUARY 17, 1984 Manuscript Accepted February 28, 198 